\title{
Morte de Deus e libertação da metáfora: uma leitura da morte de Deus em F. Nietzsche a partir da filosofia da religião de $\mathrm{G}$. Vattimo
}

\author{
Alessandro Rocha*
}

\section{Resumo}

O artigo faz uma abordagem ao tema nietzschiano da Morte de Deus visto como momento paradigmático da libertação da metáfora, ou seja, da afirmação da polissemia frente à univocidade própria da tradição metafísica. Parte-se para isso da abordagem filosófica de Gianni Vattimo seguindo o seguinte percurso: a morte de Deus como plurifontização dos loci theologici; a morte de Deus como inauguração da era hermenêutica; a libertação da dimensão metafórica da palavra teológica.

Palavras-chave: Morte de Deus; Pensiero Debole; Friedrich Nietzsche; Gianni Vattimo.

\section{Death of God and deliverance of metaphor: a reading of the death of God in F. Nietzsche from the philosophy of religion G. Vattimo}

\begin{abstract}
The article presents an approach to the theme of the Death of God nietzschiano seen as paradigmatic moment of liberation of metaphor, ie the assertion of polysemy front univocity own tradition of metaphysics. Party to this philosophical approach of Gianni Vattimo percurso using the following: the death of God as the multi-loci fontização theologici; the death of God as was the inauguration of hermeneutics, the release of the metaphorical dimension of the theological word.
\end{abstract}

Keywords: Death of God; Pensiero Debole; Friedrich Nietzsche; Gianni Vattimo.

* Pesquisador da Cátedra Unesco de Leitura da PUC-Rio, Doutor em Teologia pela PUCRio, Pós-doutorando em Letras pela PUC-Rio. E-mail: buenomartir@gmail.com . 


\section{La muerte de Dios y la liberación de la metáfora: una lectura de la muerte de Dios en F. Nietzsche de la filo- sofía de la religión G. Vattimo}

\section{Resumen}

El artículo presenta una aproximación al tema de la muerte de Dios nietzschiano visto como el momento paradigmático de la liberación de la metáfora, es decir, la afirmación de la tradición frente a la polisemia univocidad propia de la metafísica. Parte de este enfoque filosófico de Gianni Vattimo percurso usando lo siguiente: la muerte de Dios como el multi-loci fontização theologici; la muerte de Dios como fue la inauguración de la hermenéutica, la liberación de la dimensión metafórica de la palabra teológica.

Palabras clave: Muerte de Dios; Pensiero Debole; Friedrich Nietzsche; Gianni Vattimo.

\section{Introdução}

A pós-modernidade marca a superação da modernidade dirigida pelas concepções unívocas dos modelos fechados, das grandes verdades, de fundamentos consistentes, da história como pegada unitária do acontecer. A pós-modernidade abre o caminho, segundo Gianni Vattimo, à tolerância, à diversidade. É a passagem do pensamento forte, metafísico, das cosmovisões filosóficas universais, das crenças verdadeiras, ao pensamento fraco, a uma ontologia fraca.

Tal passagem ocorre - na interpretação de G. Vattimo - graças ao que Friedrich Nietzsche chamou de morte de Deus. Para F. Nietzsche, Deus (uma representação linguístico-epistemológica) encontrou seu ocaso na cultura do Ocidente, e tal ocorrência fúnebre abre caminhos para a existência que até então estavam interditados pelos centros de controle, quês (sic) religiosos ou científicos. G. Vattimo interpreta a morte de Deus, em F. Nietzsche, como a possibilidade da libertação da metáfora, ou seja, da liberação do dito plural, própria de instâncias não conceituais, portanto não metafísicas.

\section{A morte de Deus como pluri-fontização dos loci theologici ${ }^{1}$}

A morte de Deus, segundo expôs F. Nietzsche, é, antes de qualquer outra coisa, a morte de uma estrutura epistemológica linguístico-teológica

\footnotetext{
A expressão loci theologici remonta à obra De locis theologicis do dominicano Melchior Cano (1509-1560). Em sua obra, M. Cano expõe sistematicamente aquilo que ele chama de "lugares teológicos". Clodovis Boff observa que por tal expressão deve-se compreender "as instâncias de argumentação, as 'sedes' ou 'domicílios' das razões teológicas. Trata-se na verdade de uma heurística ou tópica teológica - a parte do método que ensina onde encontrar (beurískein) os argumentos de autoridade em teologia" (BOFF, 1999, p. 200). Conforme expõe C. Boff, "a taxionomia dos 'lugares' de M. Cano é a seguinte: 1. Escritura, 2. Tradição, 3. Igreja Católica, 4. Concílios, 5. Igreja Romana, 6. Santos Padres, 7. Teólogos escolásticos, 8. Razão natural, 9. Filósofos, 10. História humana". (BOFF, 1999, p. 200).
} 
sobre a qual foram erigidos os cânones da Teologia Cristã em sua expressão ortodoxa, sobretudo no âmbito da dogmática. No verso da certidão de óbito de tal estrutura epistemológica está a certidão de nascimento da pluralidade de epistemologias que amparam a multiplicação de "lugares teológicos". Isso quer dizer que há uma íntima relação entre a temática da morte de Deus e da pluralidade teológica típica da pós-modernidade.

Esse deicídio que F. Nietzsche credita aos próprios religiosos ${ }^{2}$ não foi tranquilo; como se diz no interior: uma morte morrida. Foi antes uma morte matada, resultado de uma batalha por autonomia e historicidade do ser.

Ao falar dessa batalha a partir do pensamento nietzschiano, Giorgio Penzo (2000, p. 29) diz:

A polêmica com o cristianismo decadente revela-se, no fundo, como consequência lógica da polêmica com a concepção platônica, que afirma a distinção entre mundo do ser e mundo do devir. [E ainda] Na concepção platônicocristã, o devir ver-se-ia privado de sua intrínseca perfeição e seria rebaixado à condição de realidade imperfeita relativamente à realidade mítico-metafísica, a que se atribui toda a perfeição.

A morte declarada é, portanto, de uma representação linguístico-teológica de Deus. Porém, o discurso teológico, sobretudo o dogmático, forçou de tal maneira a identificação dessa representação com o Deus cristão que qualquer ataque àquele recai inevitavelmente sobre este (ROCHA, 2007, p. 125).

2 Friedrich Nietzsche (2001, p. 147-148) trata pontualmente do tema da morte de Deus, sobretudo no aforisma 125 da Gaia Ciência: "Não ouviram falar daquele louco que, à luz clara da manhã, acendeu uma lanterna, correu pela praça do mercado e se pôs a gritar incessantemente: 'Eu procuro Deus! Eu procuro Deus!'. Estando reunidos na praça muitos daqueles que, precisamente, não acreditavam em Deus, o homem provocou grande hilaridade. 'Será que se perdeu?' dizia um. 'Será que se enganou no caminho, como se fosse uma criança?' perguntava outro. 'Ou estará escondido?' 'Terá medo de nós?' 'Terá embarcado?' 'Terá partido para sempre?', assim exclamavam e riam todos ao mesmo tempo. O louco saltou para o meio deles e trespassou-os com o olhar: 'Onde está Deus?', gritou ele, 'digo-vos! Matámo-lo - vós e eu! Somos todos os seus assassinos!' Mas como foi que fizemos isso? Como fomos capazes de esvaziar o mar? Quem nos deu a esponja com que apagámos o horizonte inteiro? Que fizemos, ao desamarrarmos esta terra do seu sol? Para onde irá agora a terra? Para onde nos levará o seu movimento? Para longe de todos os sóis? Não nos teremos precipitado numa queda sem fim? Uma queda para trás, para o lado, para a frente, para toda a parte? Haverá ainda um em cima e um em baixo? Ou não erraremos através de um nada infinito? Não sentimos já o sopro do vazio? Não está mais frio? Não é sempre noite sem descanso e cada vez mais noite? Não teremos que acender as lanternas desta manhãzinha? Não ouviremos nada além do ruído dos coveiros que enterraram Deus?” (grifo nosso). 


\section{Como observou William Hamilton (1967, p. 29),}

Não há nenhuma necessidade imediata de aceitarmos que o Deus morto é o Deus da "fé"; por outro lado não podemos deixar de concluir que o Deus morto não é o Deus da idolatria, ou da falsa piedade, ou da "religião", mas o Deus da Igreja cristã histórica e da cristandade.

Para Hamilton, que representa a escola teológica chamada "Teologia da Morte de Deus", a teologia não pode reputar a crítica embutida da temática da morte Deus somente a espíritos críticos ao cristianismo. Tal crítica tem sua gênese na própria tradição cristã. Nesse sentido, ele continua:

Por que - gostaríamos de perguntar - é necessário relacionar desse modo a Igreja com a cristandade? Porque quando ela ingressou no mundo helenístico, contribuindo para criar o mundo moderno Ocidental, tornou-se indissoluvelmente ligada à tradição histórica característica. [E conclui:] Frequentemente os teólogos modernos têm descoberto, com grande constrangimento que, logicamente e linguisticamente, não é possível dissociar os ritos credos e dogmas da Igreja de seu invólucro acidental. (HAMILTON, 1967, p. 30).

A constatação da morte de Deus é, portanto, uma grande bênção para a teologia, à medida que liberta seu discurso das amarras da metafísica, que, cristalizada, gestou tão somente uma discursividade excludente. O ocaso do Deus metafísico pode significar a libertação da dimensão metafórica da linguagem, possibilitando um renovado falar teológico, que encontra na experiência da fé um lugar privilegiado. Como também indicou Rubem Alves (1972, p. 10), "o anúncio da morte de Deus não é uma reportagem sobre o sepultamento de um ser eterno, mas antes a simples constatação de um colapso de todas as estruturas de pensamento e linguagem que o teísmo oferecia”.

Tal morte, portanto,

[...] anuncia o fim de uma visão global de universo, de uma certa filosofia, de uma linguagem que articulava a experiência do homem pelo simples fato de que uma nova maneira de pensar a vida, de encarar os seus problemas, de falar, está surgindo, e que contradiz e nega, de forma radical e irreconciliável a forma velha" (ALVES, 1972, p. 10).

A questão fundamental aqui é dar as boas-vindas a essa declaração de morte, percebendo que ela representa "o universo perdendo seu centro" e ainda que "o mundo supra-sensível não tem poder eficiente" (TROTIGNON, 
1982, p. 83), no sentido de responder às questões encontradas no horizonte existencial dos homens e mulheres concretos.

É a partir da recepção da morte de Deus e da compreensão de que ela significa a libertação da dimensão plural do discurso teológico que se torna possível abrir-se à multiplicidade, à concretude da vida, onde efetivamente ocorrem as experiências humanas, e dentre elas, aquela que poderia ser dita como a mais humana: a experiência do Mistério, do Deus revelatus, que estrutura desde dentro a existência de homens e mulheres.

Como temos proposto até aqui, a constatação nietzschiana da morte de Deus - bem como a proposição heideggeriana do fim da metafísica - inaugura uma nova época e, exatamente por isso, uma nova percepção da realidade e novos meios de aproximação dela. G. Vattimo, nesse particular, profundamente influenciado ${ }^{3}$ pelo pensamento do teólogo medieval Gioacchino da Fiore ${ }^{4}$, concebe essa nova época como uma era espiritual: a era hermenêutica ${ }^{5}$.

3 G. Vattimo (2004, p. 37-54, 1999b, p. 67-88) dedica partes de algumas de suas obras para apresentar o pensamento de Gioacchino da Fiore.

4 Gioacchino da Fiore (1132-1202) foi um abade cisterciense, filósofo, místico, defensor do milenarismo e do advento da Idade do Espírito. Nascido em Celico, província de Cosenza (Itália), era filho de Maurus de Celico. Conta-se que certa vez, em peregrinação à Terra Santa, G. da Fiore aprofundou a sua fé entregando-se a um intenso misticismo, aparentemente em razão de ter presenciado uma grande calamidade, talvez uma epidemia de peste. Passou, então, a quaresma daquele ano em contemplação no Monte Tabor, onde se diz ter recebido, em visão, a inspiração divina que teria guiado o resto da sua vida.

5 Uma vez que a salvação agora assume um caráter histórico-interpretativo, pode-se dizer que ela ainda não se efetivou plenamente, mas está em curso, ou seja, a salvação se dá com a interpretação. Para nos salvarmos é preciso, pois, interpretar a Palavra de Deus na Escritura e aplicar corretamente à própria condição histórica e situação epocal. Uma vez que o próprio Cristo é a interpretação do Pai, o Verbo (Logos), a salvação para os homens também passa pela interpretação das Escrituras. É disto que G. da Fiore fala e que G. Vattimo interpreta como as "Idades do Espírito". G. da Fiore compreende a Sagrada Escritura no contexto da história. Considera a Bíblia como sendo dividida historicamente em três momentos, estádios, ou Idades da história, como ele mesmo vai sustentar. (VATTIMO, 2004, p. 42-44). A primeira Idade corresponde ao governo de Deus Pai e é representada pela Lei, pelo poder absoluto. Marcada pelo temor ao Deus "totalmente outro", pela escravidão à lei e, portanto, pela violência metafísica (como já vimos em outra parte deste trabalho), no sentido de que não se abre para o diálogo, mas somente requer contemplação, adoração e obediência servil. Esta Idade está compreendida nos textos do Antigo Testamento. A segunda Idade, G. da Fiore denomina como a "Idade da Graça", ou seja, a da revelação do Novo Testamento. É caracterizada não mais pela escravidão, mas pela servidão filial, voluntária, por amor ao Cristo e aos outros. Isto implica no exemplo da pessoa do Filho que se dá pela kenosis, compartilhando a "lama" da humanidade e não mais marcada pela contemplação, senão agora pela ação. Esta Idade nos é contemporânea, por se tratar do estádio em que nos encontramos em nossa condição presente. Finalmente, a terceira se caracteriza pela liberdade e se assume na Pessoa do Espírito. Isto significa 


\section{A morte de Deus como inauguração da era hermenêutica. A hermenêutica como koiné da pós-modernidade}

A morte de Deus nos comunica o fato de que foi ultrapassada a ideia do Deus da metafísica; isso, contudo, não abole o suprassensível de fato, nos diz apenas que não há um fundamento (Gründ) definitivo. Nada mais que isso. Se não há, portanto, mais um fundamento definitivo, o ser acontece na história, torna-se evento. Este é o ponto de partida que G. Vattimo estabelece para constatar que a época pós-moderna é uma era onde a hermenêtica é o koiné da cultura.

No sentido de evidenciar a importância da hermenêutica para a pósmodernidade, G. Vattimo recorre à imagem da modalidade dominante da língua grega no período helenístico: o koiné (VATTIMO, 1991, p. 55-72). A hermenêutica é o koiné de nossa cultura. "A hipótese, aventada em meados dos anos oitenta, de que a hermenêutica tivesse se tornado uma espécie de koiné, de idioma comum da cultura ocidental, não apenas filosófica ainda não parece ter sido até agora desmentida" (VATTIMO, 1999a, p. 13). G. Vattimo observa que a hermenêutica compreendida como koiné revela, sobretudo, um clima difuso, uma sensibilidade geral, ou ainda uma espécie de pressuposto ao qual todos se sentem mais ou menos convidados a prestar contas.

Em seu livro Para além da interpretação. O significado da hermenêutica para a filosofia, G. Vattimo (1999a) mostra que a superação do pensamento forte (estabilidade do ser) fundado na metafísica, acontece no horizonte da afirmação da pós-modernidade como uma era hermenêutica onde se pode dizer o ser como devir, a partir do pensiero debole. Essa, que o pensamento faz de uma forma forte a outra fraca, opera uma crítica às metanarrativas universalizantes, bem como aos discursos autorizados que naturalizam sua autoridade através do recurso à metafísica.

Seguindo o postulado nietzschiano de que não há verdade, somente interpretações, G. Vattimo teoriza acerca de uma guinada na própria compreensão de ontologia: vivemos num contexto de uma "ontologia hermenêutica". Não é que somente os fatos históricos devam ser tomados como interpretação da realidade, mas que a própria realidade - inclusive a condição humana - já é interpretação. G. Vattimo (1999a, p. 23) afirma ser importante

dizer uma inteligência espiritual para interpretar as Escrituras, outrora inacessível aos demais, cabendo-nos apenas a sua servil obediência prática. Esta profecia de G. da Fiore será a plenitude dos tempos, visto que não mais nos relacionaremos como escravos, nem tampouco como servos [embora] voluntários, mas agora como amigos (caráter de proximidade da divindade). Contudo, esta Idade do Espírito ainda não se efetivou em nosso tempo, mas trata-se de um tempo que virá: "O Império do Divino Espírito Santo". 
[...] assumir o risco de concentrar a atenção sobre a koiné hermenêutica [...] [porque só assim será possível dar um] passo na direção de uma "ontologia da atualidade", na direção de um pensamento que ultrapasse o esquecimento metafísico do ser.

A “ontologia hermenêutica" assume a perspectiva filosófica que "coloca no seu âmago o fenômeno da interpretação, quer dizer, de um conhecimento do real que não se pensa como espelho objetivo das coisas 'lá fora', mas como uma compreensão que traz consigo as marcas de quem conhece" (VATTIMO, 1999a, p. 24). A profundidade de tal proposição está na afirmação de que o sujeito cognoscitivo alcança a coisa na medida em que, reconstruindo-a como forma, exprime nesta reconstrução também a si mesmo. O Ser, exatamente por isso, não é algo a que possa alcançar fora, num exercício de objetividade. Antes, o Ser se revela no encontro. Ele é não um ponto fixo, mas um evento. É nestes termos que se pode falar de "ontologia da atualidade".

G. Vattimo observa que não existe nenhum aspecto do que é chamado mundo pós-moderno que não esteja marcado pelo alastrar-se da interpretação. Ele propõe quatro traços que deixam tal domínio da hermenêutica bastante evidente. O primeiro é "a difusão dos meios de comunicação"; o segundo é "a auto-consciência da historiografia”, onde a ideia de história já é um esquema teórico resultado de opções hermenêuticas; o terceiro é "a multiplicidade das culturas", não somente a multiplicidade, mas o impacto desta no sentido de desmentir "uma ideia unitária e progressiva de racionalidade"; o quarto é "a destruição psicanalítica da fé na 'ultimidade' da consciência”, que coloca em cheque o princípio da razão instrumental e seu método dualista de sujeito/ objeto. (VATTIMO, 1999a, p. 26).

As tendências mais ortodoxas das ciências em geral e da teologia em particular tendem a condenar tal realidade hermenêutica, identificando-a como mera relativização. A possíveis acusações como esta, G. Vattimo (1999a, p. 29) afirma que "a hermenêutica se configura como puro e perigoso relativismo só se não se leva bastante a sério as próprias implicações niilistas”. E conclui:

Posto que a "verdade da hermenêutica" como teoria alternativa a outras (e antes de tudo ao conceito de verdade como "reflexo" dos "fatos") não pode se legitimar pretendendo valer como uma descrição adequada de um estado de coisas metafisicamente estabelecido ("não existem fatos, somente interpretações”), mas deve reconhecer-se também como uma interpretação, a sua única possibilidade é de argumentar-se como tal, quer dizer, como uma "descrição" interna ou leitura sui generis da condição histórica na qual é lançada e que escolhe orientar numa direção determinada, pela qual não existem outros critérios a 
não ser os que herda, interpretando, desta mesma proveniência. (VATTIMO, 1999a, p. 29-30).

A condição hermenêutica da pós-modernidade não é, portanto, mera relativização de posturas racionalistas e objetivistas; é, antes de tudo, a afirmação de uma ontologia, de uma "nova" forma de ser no mundo. Uma questão bastante importante para nossa reflexão é que essa condição hermenêutica que a cultura atual vivencia tem profunda relação com o núcleo da fé cristã que é o tema da encarnação, sobretudo da encarnação como kenosis de Deus. É nesse sentido que G. Vattimo percebe a ligação entre ontologia niilista e kenosis de Deus.

Esse horizonte hermenêutico que serve à pós-modernidade como koiné opera uma dinâmica complexa de formação de novos lugares de verdade, onde a experiência e o encontro são os elementos para a formação de uma espacialidade fraca. Isso, porém, exige que a teologia (e também que a Igreja que busca controlar a teologia) faça sua própria peregrinação da encarnação - kenosis - ao calvário, onde com o Deus da metafísica ela também possa fenecer.

\section{A morte de $D^{\prime} E U^{\prime} S$ e do 'EU' como princípio para vida do 'eu's: Morte da metafísica e vivificação do discurso possível}

Da denúncia nietzschiana acerca do deicídio operado pela fixação da metafísica como acesso definitivo à realidade podemos depreender o ocaso da centralidade do sujeito cartesiano, ou seja, do destronamento da suficiência do juízo crítico. A partir disso, novos caminhos estão abertos para a percepção da realidade e, na perspectiva teológica, do Real nomeado Deus.

De fato, nós, filósofos e "espíritos livres", ante a notícia de que o "velho Deus morreu" nos sentimos como iluminados por uma nova aurora; nosso coração transborda de gratidão, espanto, pressentimento, expectativa - enfim o horizonte nos parece novamente livre, embora não esteja limpo, enfim os nossos barcos podem novamente zarpar ao encontro de todo perigo, novamente é permitida toda a ousadia de quem busca o conhecimento, o mar, o nosso mar, está novamente aberto, e provavelmente nunca houve tanto "mar aberto" (NIETZSCHE, 2001, p. 234).

Nietzsche não mata Deus, ele constata sua morte. Essa constatação de que "Deus morreu" está intimamente ligada à história da cultura ocidental. Dizer "Deus morreu" é declarar o fim de um fundamento último, onde até então orbitavam certos valores morais e religiosos. A morte de Deus é a morte de um paradigma, uma verdadeira mudança epocal. 
Carlos Palácio faz uma importante observação sobre a estrita identificação do cristianismo com a razão ocidental. Segundo ele, "a teologia nunca saiu do âmbito da razão ocidental, seja da razão antiga (nos primeiros séculos e até a síntese de Santo Tomás), seja da razão moderna (desde o século XVI até hoje)" (PALÁCIO, 1997, p. 79). E continua afirmando:

Desde a sua origem, viu-se às voltas com a "razão": quer no encontro do cristianismo com o helenismo (civilização da razão por excelência), quer durante a sua convivência, duas vezes milenar, com a cultura ocidental. Não seria descabido, portanto, dizer que a teologia teve até hoje um único paradigma: o da razão ocidental. Nem é de estranhar que ela sofra também os impasses da crise dessa razão. De modo particular nos dois aspectos sob os quais se manifesta mais agudamente essa crise: a depauperação do conhecimento como saber e o ocultamento de Deus (PALÁCIO, 1997, p. 83).

O que vinha definhando, embora fosse envidado todo esforço para que isso não acontecesse, era uma matriz cultural que havia sido cristalizada, uma mediação cultural transformada em norma, tanto para a reflexão teológica quanto para as experiências da fé.

Mesmo percebendo que a declaração nietzschiana tem um alcance ainda mais vasto, pode-se dizer que ela se volta contra um discurso teológico que identificou o Deus cristão com uma representação cultural. A crise causada pelo definhamento da metafísica coloca em cheque a cultura cristã e a ideia de Deus dele derivada. Como afirma G. Penzo (2001, p. 31),

Para o homem metafísico, a morte de Deus é vivida de modo dramático, justamente porque marca o fim de um longo desejo que é necessário ao homem para viver com uma consciência de segurança. Nietzsche faz sua essa angústia "desesperada" do homem metafísico diante do "advento do niilismo". Supera, porém, tal angústia, quando observa que a morte de Deus é um acontecimento cultural e existencial necessário para purificar a face de Deus e, por conseguinte, a fé em Deus.

G. Penzo (2001, p. 31) ainda afirma que "Nietzsche não mata Deus, mas limita-se a constatar a ausência do divino na cultura de seu tempo, acusando, pelo contrário, por essa ausência e morte, o pensamento metafísico". Essa é uma questão que a teologia ainda não enfrentou com a profundidade necessária'. Como disse o próprio F. Nietzsche (2001, p. 135): "Deus está

Tal temática já havia sido proposta por Dietrich Bonhoeffer na década de quarenta do século XX. Contudo a lucidez de seu pensamento só seria percebida tardiamente, sobretudo a partir dos estudos do bispo anglicano John A. T. Robinson na década de sessenta. Para 
morto; mas tal como são os homens, durante séculos ainda haverá cavernas em que sua sombra será mostrada - quanto a nós - nós teremos que vencer também a sua sombra".

Compreender a profundidade das implicações dessa temática introduz a teologia numa "nova época". Como observa Roberto Machado (2002, p. 48): “A expressão 'morte de Deus' é a constatação da ruptura que a modernidade introduz na história da cultura com o desaparecimento dos valores absolutos, das essências, do fundamento divino". Como propõe G. Vattimo, F. Nietzsche não somente radicaliza a modernidade, mas antecipa em algumas décadas a pós-modernidade.

A contribuição fundamental do ataque nietzschiano à metafísica, própria da razão ocidental, aprofundada, sobretudo a partir do cartesianismo, consiste no questionamento de abordagens essencialistas. Desta forma, o discurso e a experiência humana sobre qualquer realidade, mesmo a divina, deverão assumir sua irredutível condição histórico-cultural.

Nenhuma fala pode pretender uma identificação com a realidade que não seja aquela que circunda quem a propõe. As narrativas estão condenadas aos limites daqueles que as pronunciam. Nenhuma suposta revelação divina pode potencializar discursos, conferindo-lhe alcance universal e uma decorrente univocidade.

Dessa condenação ao concreto, ao culturalmente delimitado, ao existencialmente experimentável, emerge no pensamento nietzschiano a ideia do "Super-homem". Mesmo não podendo esgotar aqui o alcance dessa ideia, interessa a relação desse "Super-homem" com a realidade concreta que F. Nietzsche representa como a terra, no sentido de lugar ou situação, remetendo sempre ao horizonte concreto onde homens existem.

Eu vos apresento o Super-homem! O Super-homem é o sentido da terra. Diga a vossa vontade: seja o Super-homem, o sentido da terra. Exorto-vos, meus irmãos a permanecer fiéis à terra e a não acreditar em quem vos fala de esperanças supra-terrestres... Noutros tempos, blasfemar contra Deus era a maior das blasfêmias; mas Deus morreu e com ele morreram tais blasfêmias. Agora, o mais espantoso é blasfemar da terra, e ter em maior conta as entranhas do impenetrável do que o sentido da terra. (NIETZSCHE, 2000, p. 25).

Em Assim falou Zaratustra, F. Nietzsche constata a morte de Deus, a descrença no além, em sua capacidade de comunicar sentido existencial aos homens e mulheres. E o que oferece em troca? "Não mais um além, mas um depois, um tempo posterior, algum dia” (MACHADO, 2002, p. 49).

aprofundar o seu pensamento, ver Bonhoeffer (2003). Vale a pena destacar, sobretudo as cartas de 30.4.1944, 5.5.1944, 25.5.1944, 30.6.1944. Para aprofundar a divulgação do pensamento de D. Bonhoeffer, ver Robinson (1967). 
O que é de grande valor num homem é ele ser uma ponte e não um fim; o que se pode amar num homem é ele ser uma passagem, um acabamento. Eu só amo aqueles que sabem viver como se extinguindo, porque são esses os que atravessam de um lado para o outro... Amo os que não procuram por detrás das estrelas uma razão para sucumbir e oferecer-se em sacrifício, mas se sacrificam pela terra, para que a terra pertença um dia ao Super-homem (NIETZSCHE, 2000, p. 27).

Como diz Roberto Machado (2002, p. 46), "Super-homem é todo aquele que supera as oposições terreno-extraterreno, sensível-espiritual, corpo-alma; é todo aquele que supera a ilusão metafísica do mundo do além e se volta para a terra, dá valor à terra”. Assumir essa metáfora nietzschiana, que na morte de Deus diz a morte da metafísica e no surgimento do Super-homem vê emergir o imperativo da vida concreta, pode levar o discurso teológico para um outro caminho que não aquele da univocidade essencialista.

Assumir que não há um eixo gravitacional a partir do qual toda realidade deve ser compreendida, mas tantos eixos quantas forem as realidades localmente situadas, pode permitir um discurso teológico que, ao sistematizar uma experiência de fé, assuma a mediação cultural própria à comunidade onde se originou aquela experiência. Dessa forma, a experiência com o Deus revelatus ganha uma nova topografia: o cotidiano mais concreto e comezinho.

Em suma, a contribuição desse capítulo do pensamento nietzschiano à teologia está na libertação da dimensão metafórica do discurso. Não há mais a obrigação de dizer o unívoco, pode-se agora abrir-se à multiplicidade polissêmica e a toda discursividade na experiência e comunicação da fé.

\section{A libertação da dimensão metafórica da palavra teológica}

Não há mais um centro de gravidade, como lugar estável, seguro e regulador a partir do qual se erija a realidade. É necessário negar o jogo da metafísica que se funda e se constrói a partir de uma imobilidade fundadora e de uma certeza tranquilizadora.

É nesse sentido que se encontra o pensamento de G. Vattimo. Ele parte do pensamento nietzschiano acerca da morte de Deus (do Deus metafísico) tomando-o como uma abertura à possibilidade de crer no Deus de Jesus, sobretudo, a partir de seu enfraquecimento ou "kenotização". Trabalha também o conceito de libertação da metáfora e negação das metanarrativas filosóficas ou teológicas, apontando dessa forma novas possibilidades à teologia na recepção e comunicação da experiência do Deus revelatus.

Com relação à possibilidade de crer, aberta pela declaração nietzschiana da morte de Deus, G. Vattimo (2004, p. 9) começa dizendo: “O anúncio de 
Nietzsche, segundo o qual 'Deus morreu', não é tanto, ou principalmente, uma afirmação de ateísmo, como se ele estivesse dizendo: Deus não existe". G. Vattimo observa esse não ateísmo nietzschiano como coerência do pensamento de tal filósofo. Ele continua: "Uma tese do gênero, a não existência de Deus, não poderia ter sido professada por Nietzsche, pois do contrário a pretensa verdade absoluta que esta encerraria ainda valeria para ele como um princípio metafísico, como uma 'estrutura' verdadeira do real que teria a mesma função do Deus da metafísica tradicional" (VATTIMO, 2004, p. 9).

Para G. Vattimo, a percepção nietzschiana da morte de Deus rompe as amarras epistemológicas que atavam o discurso filosófico e teológico a postulados unívocos.

De forma muito simplificada, creio poder dizer que a época na qual vivemos hoje, e que com justa razão chamamos pós-moderna, é aquela em que não mais podemos pensar a realidade como uma estrutura ancorada em um único fundamento, que a filosofia teria a tarefa de conhecer e a religião, talvez, a de adorar (VATTIMO, 2004, p. 11).

Batendo a golpes de martelo naquilo que se pretendia constituir como o "fundamento único" para toda a realidade, F. Nietzsche, na leitura de G. Vattimo, está liberando a experiência religiosa e seus discursos mais ou menos elaborados, para se expressar a partir de outros núcleos culturais e linguísticos. Diz ele: "Sob a luz da nossa experiência pós-moderna, isto significa que justamente porque este Deus fundamento último, que é a estrutura metafísica do real, não é mais sustentável, torna-se novamente possível uma crença em Deus" (VATTIMO, 2004, p. 12).

Contrário a toda negação que a metafísica faz quanto à legitimidade do múltiplo, do plural, o pensamento de G. Vattimo possibilita encontrar no pluralismo um princípio, além de legítimo, fecundo para a experiência de Deus. Cessa-se a negação da existência como não ser e a tendência de afirmar estruturas essenciais.

Com base na experiência do pluralismo pós-moderno, podemos somente pensar o ser como um evento, enquanto a verdade não mais pode ser o reflexo de uma estrutura eterna do real e sim uma mensagem histórica que devemos ouvir e à qual somos chamados a dar uma resposta. Uma tal concepção da verdade não é válida apenas para a teologia e a religião, mas, igualmente, para grande parte das ciências hoje (VATTIMO, 2004, p. 13). 
É na dimensão do pluralismo que se pode recuperar a legitimidade do múltiplo, que desde o encontro do cristianismo com a cultura helênica vinha sendo negado, ou identificado como heresia. O múltiplo, o plural, é a outra fala, a fala do outro, que tem tanta relevância para sua comunidade religiosa e cultural quanto a fala do eu tem para a sua.

$\mathrm{Na}$ relativização contida no plural está o princípio de afirmação do outro. Não como extensão do eu e de sua verdade - isso possibilitaria o discurso unívoco (o outro seria um eu exteriorizado) - mas como ser autônomo, histórico, cultural e religioso. Esse outro pode não orbitar do mesmo eixo do eu. Isso quer dizer que os discursos não estão contrapostos num binômio verdadeiro $\mathrm{x}$ falso, pois não há um absoluto ao qual deva corresponder o primeiro ou negar o segundo, mas eles encerram as compreensões acerca da realidade própria de seus horizontes culturais (ROCHA, 2007, p. 135).

Isso coloca uma nova tarefa diante da teologia: Como pensar os temas da fé no sentido de afirmar sua importância para a comunidade dos crentes e, ao mesmo tempo, perceber os limites que determinado sistema possui? Em aceitando a universalidade dos temas da fé, como não aceitar a universalidade do discurso? Este não é realmente um problema à medida que se consegue perceber que universalidade dos temas não corresponde necessariamente à universalidade do discurso. Os temas não se dão unicamente a uma perspectiva discursiva, embora a ortodoxia o queira, mas eles estão abertos à dinâmica hermenêutica das comunidades que os acolhem.

Todo discurso teológico é, portanto, um discurso. Toda experiência de fé é uma experiência. Isso não lhes esvazia de sua autoridade e relevância, porém as limita à extensão da comunidade a quem se destinam primeiramente, ou seja, àqueles e àquelas que partilham do mesmo horizonte histórico-cultural onde experiências e teologias são realizadas.

Nessa direção, afirma-se ainda a contribuição de G. Vattimo (2004, p. 25), quando elabora aquilo que ele chama de libertação da metáfora:

E, pois bem, hoje parece que um dos principais efeitos filosóficos da morte do Deus metafísico e do descrédito geral ou quase, em que caiu todo o tipo de fundamento filosófico, foi justamente o de ter criado um terreno fértil para uma possibilidade renovada da experiência religiosa. Tal possibilidade retorna [...] por meio da libertação da metáfora. É um pouco como se, no final, Nietzsche tivesse razão ao preconizar a criação de muitos novos deuses: na Babel do pluralismo de fins da modernidade e do fim das metanarrativas, se multiplicam as narrativas sem um centro ou uma hierarquia.. 
G. Vattimo observa que a libertação da metáfora é a libertação da experiência em perspectiva plural. É a possibilidade de dizer a própria experiência não com os signos dos dominadores, mas a partir da própria realidade. $\mathrm{Na}$ libertação da metáfora nega-se a hegemonia do discurso unívoco, que se pretendia regulador de toda discursividade.

A apologética, enquanto aparelho de coerção, foi enquadrando toda diversidade discursiva, harmonizando-a sob pena de sanções pesadíssimas, de anatematizações vexatórias e rotulação de heresia. Teorizando sobre essa dinâmica de controle, G. Vattimo (2004, p. 26) observa que "somente ao se estabelecer uma sociedade e uma casta de dominadores nasce a obrigação de se 'mentir segundo uma regra estabelecida', ou seja, de se usar, como única língua 'apropriada', as metáforas dos dominadores"; o resultado de tal procedimento de coerção acaba "fazendo com que as outras linguagens sejam degradadas a condição de puras linguagens metafóricas, ao campo poético".

Tal processo de dominação da linguagem a partir da recepção e naturalização da regra metafísica na gramática da cultura é muito profundo. Libertar-se dele, contudo, é vital. Fazê-lo, porém, é uma tarefa continua.

Naturalmente, a libertação da metáfora de sua subordinação a um sentido próprio só aconteceu em linha de princípio, pois na prática, na sociedade pluralista, ainda estamos longe de ver realizada uma perfeita igualdade entre as formas de vida (culturas diversas, grupos, minorias, etc., de vários tipos) expressas pelos diferentes sistemas de metáforas (VATTIMO, 2004, p. 26).

\section{Apontamentos em forma de conclusão}

É exatamente no sentido de dar continuidade a esse processo que $G$. Vattimo diz estar incompleto, que se toma aqui a questão da libertação da metáfora como "pano de fundo" para a proposição de um ampliado campo semântico, onde se possa operar uma racionalidade aberta que permita à discursividade teológica expressar-se nesse nosso tempo pós-moderno. Nesse "pano de fundo", inserimos outros dois importantes elementos do pensamento de G. Vattimo: o pensiero debole e sua interpretação sobre a kenosis.

Porém, não podemos encerrar esse tópico sem levar em consideração os desdobramentos da fixação de tal pano de fundo como cenário próprio à racionalidade teológica no contexto pós-moderno. Como diz G. Vattimo (2004, p. 64),

O reconhecimento de direitos iguais para as culturas outras que no plano político ocorreu com o final do colonialismo e no plano teórico com a dissolução das "metanarrativas" eurocêntricas, no caso das Igrejas cristãs exige o 
abandono dos comportamentos "missionários", isto é, da pretensão de levar ao mundo pagão a verdade única.

Aqui se encontra a radicalidade que a tese da morte de Deus propõe à teologia. Explodida a unicidade epistemológica, libertada a condição metafórica frente à verdade, a teologia é convidada a perceber os limites de seu discurso. G. Vattimo explora esse convite levando-o às suas mais profundas consequências.

O reconhecimento da verdade das outras religiões [...] requer um esforço intensificado para desenvolver a leitura espiritual da Bíblia e também de tantos dogmas da tradição eclesiástica, de maneira a que se possa colocar em evidência o cerne da revelação, ou seja, a caridade, mesmo à custa, obviamente, do enfraquecimento das pretensões de validade literal dos textos e de peremptoriedade do ensinamento dogmático das igrejas (VATTIMO, 2004, p. 64).

Isso tudo significa que não estamos somente diante de uma reformulação da explicitação da doutrina, coisa que poderia ficar na epidérmica dimensão da oratória. Mas nos encontramos face ao chamado de conversão das nossas estruturas mentais, de nossa forma de compreensão da realidade e dos meios de apreendê-la e nomeá-la. Na perspectiva de G. Vattimo, estamos diante da passagem do modo de ser derivado do pensamento forte ao modo de ser próprio do pensamento fraco.

\section{Referências}

ALVES, Rubem. Deus Morreu - Viva Deus! In: ALVES, Rubem; MOLTMANN, Jürgen. Liberdade e Fé. Rio de Janeiro: Tempo e Presença, 1972.

BOFF, Clodovis. Teoria do método teológico. 2. ed. Petrópolis: Vozes, 1999.

BONHOEFFER, Dietrich. Resistência e Submissão. Cartas e anotações escritas na prisão. São Leopoldo: Sinodal, 2003.

Hamilton, William. A Morte de Deus. Introdução à Teologia Radical. Rio de Janeiro: Paz e Terra, 1967.

MACHADO, Roberto. Zaratustra. Tragédia nietzschiana. São Paulo: JZE, 2002.

NIETZSCHE, Friedrich. A Gaia Ciência. São Paulo: Companhia das Letras, 2001. . Assim Falou Zaratustra. São Paulo: Martin Claret, 2000.

PALÁCIO, Carlos. Novos paradigmas ou fim de uma era teológica? In: ANJOS, Marcio Fabris dos. Teologia aberta ao futuro. São Paulo: Loyola, 1997.

PENZO, Giorgio. Friedrich Nietzsche. O divino como problematicidade. In: PENZO, Giorgio; GIBELLINI, Rosino (Org.). Deus na Filosofia do Século XX. 2. ed. São Paulo: Loyola, 2000 
ROBINSON, John A. T. Um Deus Diferente. Lisboa: Morais, 1967.

ROCHA, Alessandro. Teologia sistemática no horizonte pós-moderno. São Paulo: Vida, 2007.

VATTIMO, Gianni. A tentação do Realismo. Rio de Janeiro: Lacerda, 2001.

. Hermenéutica: Nuova koiné. In:

. Ética de la Interpretación. Barcelona:

Paidós, 1991.

. Os ensinamentos de Gioacchino. In:

Depois da cristandade. Rio de Janeiro: Record, 2004. p. 37-54.

Para além da Interpretação: o significado da hermenêutica para a filosofia. Rio de Janeiro: Tempo Brasileiro, 1999a.

. Religião. In:

Para além da interpretação. O significado da hermenêutica para a filosofia. Rio de Janeiro: Tempo Brasileiro, 1999b. 